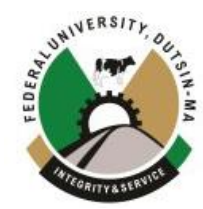

\title{
PERFORMANCE OF TEN (10) VARIETIES OF SESAME (Sesamum Indicum) GROWN IN BILLIRI, GOMBE STATE, NIGERIA.
}

\author{
Madina Paul. \\ Department of Crop Production, College of Agronomy, University of Agriculture, Makurdi, Benue State, Nigeria. \\ Corresponding Author’s email: madinapaul26@yahoo.com,+2348189945123
}

\begin{abstract}
A field experiment was carried out in the rainy season of 2019 in Gombe states, Nigeria. The experiment was carried out in Tal, Billiri Local Government, Gombe State. The aim of the experiment was investigate the performance of ten varieties of sesame. The ten different varieties were; E-8, NCRIBEN-01, NCRIBEN-02, NCRIBEM-031, YANDEV-55, EX-BR-1, EX-BR-2, E-SUDAN, 560-1 and LOCAL. The treatments were laid in a randomized complete block design with three replications. The treatments were combined to have 10 plots in a block with 1 meter between the block and 0.5 meters within the plots. The seeds were placed in $5 \mathrm{~cm}$ depth at the spacing of $15 \times 75 \mathrm{~cm}$. During the research growth parameters like plant height, number of leaves and number of branches were measured. Other growth parameters like days of $1^{\text {st }}$ flower, $50 \%$ flower, days of maturity, number of capsule per plant, seeds per capsule, number of capsule per leaves axis, 1000 seed weight and seed yield were also recorded. The results of the experiment revealed that sesame generally responded to both varietal and fertilizer effects. All the parameters studied have significantly $(\mathrm{P} \leq 0.05)$ responded to the varietal effects, here variety NCRIBEN-01 and E-8 were observed to perform higher in both growth parameters, yield related character and overall yield. Based on the result obtained it can be suggested that the use of E-8, NCRIBEN-01, NCRIBEN-02, NCRIBEN-031, YANDEV-55 will give high yield followed by EX-BR-1, EX-BR-2, E-SUDAN and 506-1 leading to optimum yield for farmers in Tal, Billiri Local Government, Gombe State.
\end{abstract}

Keywords: Renewable energy, wind energy, weibull distribution, wind speed.

\section{INTRODUCTION}

Sesame (Sesanum indicum L.) is an annual flowering plant which is cultivated for its seeds. The plant grows to produce pods and it believed to be oldest cultivated oil seed in the world. Commonly refers to as beniseed is one of the cultivated oil seed crops of the world. It is believe to be originated from Africa; it was introduced into Nigeria after the second world war and was mostly cultivated as a minor crop in the northern and central part of Nigeria until 1974 when it began to gain prominence as a major crop. Since its introduction to Nigeria after the second world war it has been regarded as a crop of insignificant importance compared to groundnut and other cash crop. The demand for beniseed and its products is growing both at national and international levels. Therefore there is a huge market potential for the crop. Because of its previous status as a minor crop, it received very little research attention. Beniseed oil is of high quality free from undesirable flavour and contained antioxidant. It is its sterling qualities that stimulate interest in the production of the crop. There are very high potentials for beniseed production in Nigeria but the average yield of $300 \mathrm{~kg} / \mathrm{ha}$ is considered too low and unattractive. Sesame ranks the eight in the world production of edible oil seed, with higher oil content than other oil seeds. It is grown mainly for its seeds that contain approximately $50 \%$ oil and $25 \%$ protein. The presence of some antioxidants (sesamum, sesamolin and sesamol) makes the oil one of the most stable vegetable oil in the world, it also content nutritional and medicinal qualities, the seeds contain essential amino acid and fatty acids and a good source of vitamins. Production must be increased in order to take advantage of huge market potential of this crop. The cultivation of sesame in Nigeria is gaining acceptance with an estimated 3.5 hectares on a sandy loam soil with a $\mathrm{PH}$ ranging from $5.5-6.7$ at a soil depth of $1.5-2.5 \mathrm{~cm}$ at a spacing of 60 x 10 or $15 \times 75$ at a seed rate of $4 \mathrm{~kg} / \mathrm{ha}$ or when broadcasting at $5 \mathrm{~kg} / \mathrm{ha}$ preferably 2 plant per stand is optimal. Prevailing agronomic and climatic condition in Nigeria should be optimized for sesame cultivation so also the use of improved variety (Van Rheenen, 1973). The objective of the work is to come up with variety or varieties that will perform well in the area.

\section{MATERIALS AND METHODS}

The experiment was carried out in Tal at $\left(9^{\circ} 50^{\prime} \mathrm{N} 11^{\circ} 09^{\prime}\right)$ Billiri Local Government of Gombe State. The aim of the experiment was to investigate the performance of ten varieties, the ten different varieties were; E-8, NCRIBEN-01, NCRIBEN-02, NCRIBEM-031, YANDEV-55, EX-BR-1, EX-BR-2, E-SUDAN, 560-1 and LOCAL as check. research and the varieties considered where as follows NCRIBEN O1M (530-6-10) matures between 102-115 days, NCRIBEN O2M (Type 4) matures between 102-115 days with $45 \%$ oil, NCRIBEM O31(Goza-25) matures between 125-140days with $45 \%$ oil, YANDEV-55 matures between $125-130$ days with $40 \%$ oil, E-8 matures between $90-95$ days with $50 \%$ oil, 560-1 matures between $130-140$ days with $40 \%$ oil, the above varieties where improved IITA (2000) while EX-BR-1 matures between 120-130 days with $40 \%$ oil, EX-BR-2 matures between 120-135 days with $40 \%$ oil, E-SUDAN matures between 130-135 days $40 \%$ oil, were cultivated in the localities for more than 5 decade and LOCAL matures between 140-145 days with 35 oil, not fully domesticated mostly found in the wild, mostly used by the villagers for soup and sometimes used to feed rabbit. The experiment that was laid in a randomized complete block design (RCBD) with three replicate, a $4 \mathrm{~m}^{2}$ plot was laid out with $1 \mathrm{~m}$ between plots and $0.5 \mathrm{~m}$ between blocks. There were 10 plots each within a block which gave the total number of 30 plots for the study, with spacing of $15 \times 75 \mathrm{~cm}$ was 
adopted for the research, Agronomic practice such as weeding was done manually at 2 and 6 weeks after planting to ensure weed free plots, all the data were collected within the net plot of $4 \mathrm{~m} 2$ /where a total of 10 plants were tagged for data collection within each net plot. The parameters recorded were plant height (was taken with the aid of measuring tape from the base of the plant to the tip), number for leaves (were counted fortnightly) from 10 plants that was tagged and the average used fortnightly and days first day of flower, days of 50\% flowering (were counted fortnightly), days of maturity, yield and yield related characters such as number of pod, number of seed per pod, number of capsule per leaves axis, pod weight and 1000 seed weight was recorded. All data collected were subjected to analysis of variance (ANOVA), while least significant difference (LSD) at $5 \%$ level of probability was used in separating the means.

\section{RESULT AND DISCUSSION}

Table1 is the performance of ten varieties of sesame on vegetative part grown in Gombe, this include plant height, number of branches and number of leaves. On plant height significance difference was observed among the variety that was used with varieties E-SUDAN having taller plant followed by 560-1 which could be attributed to soil condition, environmental condition and probably genetic makeup of such varieties, this finding is in conformity with the findings of Anon (2004) and Mulkey et al.(2017) . On number of branches significant difference existed between the varieties used with YANDEV-55 having higher number of branches followed by E-8 which is not far from the fact that environmental condition, genetic make-up and agronomic practice might have caused the difference, this work is supported by the findings of Magashi and Yusuf (2013) reported that vegetative growth leading to establishments of branches are influence by environmental condition/factors and mostly by crop genetic make-up. Significant difference was observe on number of leaves among the varieties where EX-BR-2 had higher number of leaves followed by $560-1$, this could be influenced by genetic make-up of the plant which plays a very vital role in intercepting solar radiation for photosynthetic activities as reported by Day et al (2002). Georgiev (2000) also lend support to the above accretion in his work on problems and prospect of selection of sesame. Says that environmental factors, agronomic practice and genetic make-up plays an important role in plant floral part there by affecting the crop yield.

Table 1. Performance of ten varieties of sesame on vegetative part grown in Tal, Billiri, Gombe state.

\begin{tabular}{llll}
\hline Varieties (V) & Plant Height & No. of Branches & No. of Leaves. \\
\hline E-8 & $132.01 \mathrm{c}$ & $7.32 \mathrm{~b}$ & $52.21 \mathrm{e}$ \\
NCRIBEN-01 & $121.21 \mathrm{e}$ & $5.31 \mathrm{~g}$ & $49.04 \mathrm{~g}$ \\
NCRIBEN-02 & $119.76 \mathrm{~g}$ & $5.91 \mathrm{e}$ & $50.91 \mathrm{f}$ \\
NCRIBEM-031 & $125.09 \mathrm{~d}$ & $5.61 \mathrm{f}$ & $45.99 \mathrm{i}$ \\
YANDEV-55 & $102.12 \mathrm{i}$ & $7.81 \mathrm{a}$ & $47.02 \mathrm{~h}$ \\
EX-BR-1 & $115.91 \mathrm{f}$ & $5.12 \mathrm{~h}$ & $54.21 \mathrm{~d}$ \\
EX-BR-2 & $120.84 \mathrm{~h}$ & $6.31 \mathrm{c}$ & $59.27 \mathrm{a}$ \\
E- SUDAN & $134.23 \mathrm{a}$ & $5.99 \mathrm{~d}$ & $54.81 \mathrm{c}$ \\
560-1 & $130.21 \mathrm{~b}$ & $5.00 \mathrm{i}$ & $56.46 \mathrm{~b}$ \\
LOCAL & 110.5 & 4.89 & 41.91 \\
LSD & 3.25 & 0.10 & 2.61 \\
\hline
\end{tabular}

$\mathrm{V}=$ varieties, LSD $=$ Least Significant Differences at 5\% Level of Probability.

Table 2. shows the performance of ten varieties of sesame on reproductive part grown in Gombe, this include days of first and $50 \%$ flowering, maturity and number of capsule per plant. The research recorded significant difference on days of first flowering where YANDEV-55 had early flowering, 50\% flowering and maturity followed by E-SUDAN which could not be far from its genetic make-up and probably soil, environmental condition, having in mind that YANDEV-55 is an early maturing variety between 90 95 days this could have led to its early flowering as reported by IITA (2000) and Gupta (2000) Significant difference was also recorded on number of capsule per plant where E-8 had higher number of capsule per plant followed by NCRIBEN-01 this could be attributed to genetic make-up of the crop, adoptability to climatic factor and agronomic practice as reported by the earlier work of Delgodo and Yermanos (2005). Georgiev et, al. (2011) and Ishpekov et, al. (2012)

Collaborated with the findings reported edafic factors and climatic conditions made have caused the variation.

Table 2. Performance of ten varieties of sesame on reproductive part grown in Tal, Billiri, Gombe state.

\begin{tabular}{lllll}
\hline Varieties (V) & $\mathbf{1}^{\text {st }}$ Flower & $\mathbf{5 0 \%}$ Flower & Maturity & No. of Capsule \\
\hline E-8 & $45.21 \mathrm{f}$ & $61.25 \mathrm{~g}$ & $115.01 \mathrm{e}$ & $71.01 \mathrm{a}$ \\
NCRIBEN-01 & $44.01 \mathrm{~g}$ & $67.34 \mathrm{c}$ & $110.07 \mathrm{~h}$ & $65.24 \mathrm{~b}$ \\
NCRIBEN-02 & $48.28 \mathrm{~b}$ & $68.72 \mathrm{~b}$ & $111.25 \mathrm{~g}$ & $63.91 \mathrm{c}$ \\
NCRIBEM-031 & $46.46 \mathrm{e}$ & $64.91 \mathrm{~d}$ & $140.30 \mathrm{a}$ & $61.90 \mathrm{~d}$ \\
YANDEV-55 & $28.91 \mathrm{i}$ & $40.31 \mathrm{i}$ & $90.32 \mathrm{i}$ & $58.25 \mathrm{e}$ \\
EX-BR-1 & $49.21 \mathrm{a}$ & $69.01 \mathrm{a}$ & $120.51 \mathrm{c}$ & $49.49 \mathrm{i}$ \\
EX-BR-2 & $43.21 \mathrm{f}$ & $62.21 \mathrm{f}$ & $115.39 \mathrm{~d}$ & $50.91 \mathrm{~h}$ \\
E- SUDAN & $40.91 \mathrm{~h}$ & $60.47 \mathrm{~h}$ & $122.12 \mathrm{~b}$ & $52.90 \mathrm{~g}$ \\
560-1 & $47.91 \mathrm{c}$ & $63.01 \mathrm{e}$ & $113.01 \mathrm{f}$ & $53.01 \mathrm{f}$ \\
LOCAL & 41.92 & 65.01 & 130.12 & 32.01 \\
LSD & 2.01 & 1.00 & 2.01 & 1.00 \\
\hline
\end{tabular}

$\mathrm{V}=$ varieties, $\mathrm{LSD}=$ Least Significant Differences at 5\% Level of Probability. 
Table 3 is the performance of ten varieties of sesame on yield component grown in Gombe, these are number of seeds, number of capsule per leave axis, 1000 seed weight and the overall yield. Significant difference was recorded in number of seeds per plant where NCRIBEN-01 had higher number of seeds followed by E-8, this is not far the fact that genetic make-up, rainfall and soil condition might have favoured this varieties, this work is in agreement with the work of Ashir (2007) who reported that E-8, NCRIBEN-01 and other from the same family are improve for its yielding ability which higher seeds is the major character that have been developed. The work also recorded significant difference on number of capsule per leave axis with E- 8 having higher number of capsule of leave axis, followed by NCRIBEN-01 this is purely genetic make-up of the varieties couple with favourable climatic condition leading to higher number of capsule and affecting positively the over-all crop yield as reported by Deepasankar and Anandakomar (2003). Ishpekov et al.(2015) supported the finding saying cultivars and genetic inherent characters could lead to higher capsule, seeds and over all yield.
In the same vein significant difference was recorded in the weight of 1000 seeds where E-8 had weightier 1000 seeds followed by NCRIBEN-01. his could be as a result of genetic make-up giving not only many seeds but also qualitative seeds in terms of weight which is in agreement with the work of Anitha et al (2000) who reported that most improve varieties are done for both quantity and quality. Significant difference was observe in seed yield where NCRIBEN-01 recorded higher yield followed by E-8, this could be true due to higher number of capsule per plant, higher number of capsule per leave axis, higher number of seeds and weightier seeds recorded all attributed to the above mention varieties, in addition Beech (1985) and Donald (1999) said this could not have been possible with-out the positive interaction between the crop environment and inherent character. Fekremariam et al. (2014) and Stamatov et al.(2017) also reported yield related characters/parameters such as number of capsule, number of seeds and seeds weight attribute to over all yield.

Table 3. Performance of ten varieties of sesame on yield component grown in Tal, Billiri, Gombe state.

\begin{tabular}{|c|c|c|c|c|}
\hline \multicolumn{2}{|c|}{$\begin{array}{l}\text { Varieties } \\
\text { per leave axis }\end{array}$} & $\begin{array}{l}\text { No. of capsule } \\
\text { weight }(\mathrm{kg})\end{array}$ & 1000 seed & Seedyield/ha \\
\hline$\overline{E-8}$ & $72.46 b$ & $3.31 \mathrm{a}$ & $4.01 \mathrm{~b}$ & $4.20 \mathrm{~b}$ \\
\hline NCRIBEN-01 & $75.51 \mathrm{a}$ & $3.21 \mathrm{~b}$ & $4.59 \mathrm{a}$ & $4.82 \mathrm{a}$ \\
\hline NCRIBEN-02 & $65.24 \mathrm{c}$ & $3.01 \mathrm{c}$ & $3.61 \mathrm{c}$ & $3.21 \mathrm{c}$ \\
\hline NCRIBEM-031 & $62.91 \mathrm{c}$ & $2.91 \mathrm{e}$ & $3.10 \mathrm{e}$ & $3.00 \mathrm{~d}$ \\
\hline YANDEV-55 & $58.23 \mathrm{e}$ & $2.25 \mathrm{~g}$ & $3.01 \mathrm{f}$ & $2.81 \mathrm{e}$ \\
\hline EX-BR-1 & $51.09 \mathrm{~h}$ & $2.11 \mathrm{~h}$ & $2.80 \mathrm{~h}$ & $2.51 \mathrm{f}$ \\
\hline EX-BR-2 & $56.99 \mathrm{f}$ & $2.00 \mathrm{i}$ & $2.71 \mathrm{i}$ & $2.40 \mathrm{~h}$ \\
\hline E- SUDAN & $50.01 \mathrm{i}$ & $2.43 \mathrm{f}$ & $2.99 \mathrm{~g}$ & $2.21 \mathrm{i}$ \\
\hline $560-1$ & $53.21 \mathrm{f}$ & $3.00 \mathrm{~d}$ & $3.32 \mathrm{~d}$ & $2.99 \mathrm{~g}$ \\
\hline LOCAL & 42.91 & 1.89 & 1.90 & 1.51 \\
\hline LSD & 3.01 & 0.05 & 0.80 & 1.01 \\
\hline
\end{tabular}

\section{CONCLUSION}

In conclusion the result obtained from the research suggest that the use of E-8, NCRIBEN-01, NCRIBEN-02, NCRIBEN-031, YANDEV-55 will give high yield followed by EX-BR-1, EX-BR-2, E-SUDAN and 506-1 leading to optimum yield for farmer in the location. EX-BR-1, EX-BR-2, E-SUDAN, 560-1 and Local variety can be improved by breeders to maximize its potential, since they are verities that have been cultivated for decades.

\section{REFERENCES}

Anitha Vasline,Y. Saravannah, and Ganesan, J. (2000). Studies on Variability and genetic advance for certain characters in mutant populations of sesame (Sesamum indicum L.). News: 15: 39 - 43.

Anon (2004). Research report on hybrid sunflower, sesame and spelt crop insurance programs. P. 1 - 96 Watts and Associates, Billings, M.T.

Ashir, A. (1985) Sesame improvement by large scale cultivars intercrossing and by crosses with indehehiscent and determinant line Pg. $177-181$.

Ashir A. (2007) Sesame (Sesame indreum L.), genetic resources, chromosome engineering, and crop improvement. Vol 4. oil seed crops CRS, Press, Boca Raton, FL. P. $231-289$.
Beech, D.F (1985) Sesame Research Possibilities for Yield Improvement Pg. 96 - 106.

Day, J.S., D.R Langhan and Wowongyai (2002) Potential selection criteria for the development of high yielding determinate sesame cultivars Pg. $29-35$.

Deepa sankar P. and Ananda Komar CR (2003). Genetic analysis of yield and related components in sesame (Sesmum indreum L.) Crop Res. 5 (1) $91-95$

Delgodo, M. and Yermanous D.M (2005) Yield components of sesame (sesmum indreum L.) under different population densities economic botany, 291(1) : $69-78$.

Donald, C.M (1999) Competition among crop and pasture plants Advances in Agronomy, 291(1):69 - 78.

Fekremariam A, Yayeh B, Mitiku A, Minale L, Wudu G (2014). Row Spacing and Fertilizer Rate on Yield and Yield Components of Tef Eragrostis Teff (Zucc.) rotter) under Transplanting Planting Method. Journal of Biology and Agricultural Healthcare 4:133-136. 
Georgiev, S., 2000. State, Problems and Prospects of selection of sesame in Bulgaria. Bulgarian journal of agricultural science, ISSN 1310-0351. 3, p. 18-21 (BG).

Georgiev, S., S. Stamatov, M. Deshev., 2011. Analysis of heterosis and combining ability in some morphological characters in sesame (Sesamum indicum L.). Bulgarian journal of agricultural science, ISSN 1310-0351, vol. 17, 4 p. 456-464.

Gupta T.R. (2000) Effect of plant density on yield and yield components in sesame (Sesamum Inducin L.). Madras Agricultural Journal, 69 (9): 560 - 573.

Ishpekov S., R. Zaykov, V. Chervenkov., 2015 a. Inertial detachment of sesame seeds from non-squander genotypes. Agric Eng Int: CIGR Journal. Vol. 17, No. 3, ISSN 1682-1130.

Ishpekov, S., P. Petrov, A. Triffonov, I. Dimitrov, Z. Mihaylova, D. Aleksandrov, S. Stamatov, M. Deshev, B. Kolev., 2012. Indices for picking single sesame capsules. Bulgarian Journal of Agricultural Science, ISSN 1310-0351, 18 (No 4) 18: 635-640, ISSN 1310-0351, (BG).

Magashi, D. and Yusuf, H.I (2013) Planting Date Effect on Plant Growth and Development in Sesame. Agron. J. 79: 701-703.
Mulkey JR, Drawe Jr. HI, Elledge RE (2017). Planting Date Effect on Plant Growth and Development in Sesame. Agron. J. 79: 701703.

Stamatov, St., Ishpekov, S., Deshev, M., Zaykov, R., (2017). Application of the independent subjective evaluation method of the hybrid material in the breeding of sesame (Sesamum indicum L). Bulgarian Journal of Agricultural Science, ISSN 1310- 0351, 23 (No 4) 2017, 584-588.

Stone bridge, W.C (1963), Beniseed Variety and sowing method trial. Technical reports of institute for agricultural research North, Nigerian $281-9$.

Van Rheenen, H.A (1973). Major Problems of growing sesame in Nigeria. Communication Agricultural University, Wangeningen, Hoiland Pg. 130. 